\title{
PENILAIAN JUMLAH NEUTROFIL, LIMFOSIT DAN TROMBOSIT, KADAR PROTEIN REAKTIF C, KADAR ALBUMIN, RASIO NEUTROFIL LIMFOSIT, SERTA RASIO TROMBOSIT LIMFOSIT SEBELUM DAN SETELAH TERAPI PADA PENDERITA KARSINOMA PAYUDARA
}

\author{
Benny Hartono \\ Victor S. Pontoh \\ Marselus A. Merung \\ Bagian Bedah Sub Bagian Bedah Onkologi RSUP Prof. Dr. R. D. Kandou/
Fakultas Kedokteran Universitas Sam Ratulangi Manado
Email: bnny_hartono@yahoo.com
}

\begin{abstract}
Breast carcinoma is a type of carcinoma that has sufficiently high prevalence and can occur in men and women, with a much higher prevalence in women. In addition to the high number of cases, more than $70 \%$ of patients with breast carcinoma was found at an advanced stage. There are several studies measuring markers of inflammation and the levels of albumin in the search for an independent prognostic association in various carcinomas. The ratio of neutrophils to lymphocytes, ratio of platelets to lymphocyte, C-reactive protein, and albumin are predictors in analyzing the changes that occur before and after treatment (chemotherapy and/or surgery) in patients with breast carcinoma. This was an interventional analytical study with a cross-sectional design, conducted in Prof. Dr. R. D. Kandou Hospital Manado during the period of May 2014 to April 2015. The results showed that there were 43 females with breast carcinoma with an average age of 52.16 years. The state dof carcinoma were as follows: stage IIIA 5 patients (11.6\%), IIIB 25 patients (58.1\%), IIIC 11 patients (25.6\%), and stage IV 2 patients (4.7\%). Modality of chemotherapy plus surgery was performed on 40 patients (93\%), chemotherapy only on 2 patients (4.7\%), and surgery only on 1 patient (2.3\%). Among the treated patients there were significant declines in the value of neutrophils, platelets, C-reactive protein, neutrophil lymphocyte ratio, and platelet lymphocyte ratio, moreover, there were significant inclines in lymphocytes and albumin. Conclusion: Modality of chemotherapy and/or surgery in patients with breast carcinoma significantly affected the haemopoetic process (declines of neutrophil and platelet counts, NLR and TLR values), declined CRP levels, but inclined lymphocyte count as well as albumin levels when compared before and after treatment.
\end{abstract}

Keywords: breast carcinoma, C-reactive protein, albumin, neutrophil lymphocyte ratio, thrombocyte lymphocyte ratio

\begin{abstract}
Abstrak: Karsinoma payudara (KPD) merupakan salah satu jenis karsinoma yang memiliki prevalensi cukup tinggi dan dapat terjadi pada pria maupun wanita, dengan prevalensi yang jauh lebih tinggi pada wanita. Selain jumlah kasus yang tinggi, lebih dari 70\% penderita KPD ditemukan pada stadium lanjut. Terdapat beberapa penelitian mengukur petanda peradangan dan kadar albumin dalam mencari kaitan prognostik independen pada berbagai karsinoma. Rasio neutrofil limfosit, rasio trombosit limfosit, protein reaktif $\mathrm{C}$, dan albumin menjadi prediktor dalam menganalisis perubahan yang terjadi sebelum dan setelah terapi (kemoterapi dan/atau operasi) pada pasien KPD. Penelitian ini merupakan penelitian intervensional analitik
\end{abstract}


dengan desain potong lintang, yang dilakukan di RSUP Prof. Dr. R. D. Kandou Manado selama periode Mei 2014 - April 2015. Hasil penelitian mendapatkan 43 pasien KPD yang dirawat dengan usia rata-rata 52,16 tahun. Keadaan karsinoma stadium IIIA pada 5 pasien (11,6\%), IIIB 25 pasien (58,1\%), IIIC 11 pasien (25,6\%), dan stadium IV 2 pasien (4,7\%). Pemberian modalitas kemoterapi dan operasi pada 40 pasien (93\%), hanya kemoterapi 2 pasien (4,7\%), dan hanya operasi 1 pasien (2,3\%). Terjadi penurunan bermakna pada nilai hitung neutrofil dan trombosit, protein reaktif $\mathrm{C}$, rasio neutrofil limfosit dan rasio trombosit limfosit pada pasien yang diterapi. Selain itu terjadi peningkatan bermakna pada nilai hitung limfosit dan albumin. Simpulan: Tindakan yang diberikan baik kemoterapi dan/atau operasi pada pasien karsinoma payudara memengaruhi proses hemopoetik (penurunan hitung neutrofil, trombosit, nilai NLR, nilai TLR) dan penurunan kadar CRP, serta peningkatan limfosit dan kadar albumin saat dibandingkan sebelum dan setelah diberikan perlakuan.

Kata kunci: karsinoma payudara, protein reaktif C, albumin, rasio neutrofil limfosit, rasio trombosit limfosit

Karsinoma payudara (KPD) merupakan salah satu jenis karsinoma yang memiliki prevalensi cukup tinggi dan dapat terjadi pada pria maupun wanita, dengan prevalensi yang jauh lebih tinggi pada wanita. Pada tahun 2011, di Amerika Serikat terdapat 230.480 kasus baru KPD pada wanita dan 2.140 kasus baru pada pria, dengan 39.520 kasus kematian pada wanita dan 450 kasus kematian pada pria. ${ }^{1}$ KPD merupakan karsinoma dengan jumlah terbanyak di Indonesia, khususnya pada wanita (17,77-19,52\%). Selain jumlah kasus yang tinggi, lebih dari 70\% penderita KPD ditemukan pada stadium lanjut. Hal tersebut yang menyebabkan tingginya angka kematian pada kasus KPD. ${ }^{2}$

Telah diketahui bahwa variasi hasil keluaran penderita karsinoma tidak hanya semata ditentukan dari karakteristik tumor tetapi juga faktor respons inang. Keadaan inflamasi dapat mempercepat pertumbuhan tumor, invasi, angiogenesis, dan bahkan metastasis. Peningkatan petanda peradangan (protein reaktif $\mathrm{C}$ ) berhubungan dengan menurunnya ketahanan hidup penderita KPD. Juga terdapat hubungan antara petanda peradangan sederhana (seperti neutrofil, limfosit, dan trombosit darah tepi) dan hasil keluaran karsinoma. ${ }^{5}$

Hubungan antara tingginya rasio neutrofil terhadap limfosit dan buruknya prognosis sangat kompleks. Pada percobaan kultur neutrofil dan limfosit dari donor penderita karsinoma, neutrofil terkait tumor melalui reaksi enzimatik memicu pemben- tukan matriks ekstrasel baru yang menghasilkan pelepasan faktor pertumbuhan fibroblas dasar, migrasi sel endotel, dan disosiasi sel karsinoma. Selain itu, spesies oksigen reaktif yang dihasilkan neutrofil menurunkan sifat adhesi dan properti promosi dari matriks ekstrasel serta menghambat apoptosis sel tumor melalui aktivasi nuclear factor (NK)-кB. Peristiwa ini mengakibatkan peningkatan angiogenesis, pertumbuhan tumor, dan perkembangan ke fenotip metastatik. Pada KPD, oncostatin $M$ yang disekresi oleh neutrofil memberi sinyal ke sel-sel payudara untuk menghasilkan vascular endothelial growth factor (VEGF) dan meningkatkan pelepasan sel karsinoma. ${ }^{7}$

Sehubungan dengan keganasan, limfosit menekan maturasi tumor. Limfosit sitotoksik T (CTLs) menginduksi apoptosis sel-sel karsinoma melalui interaksi molekul CD95L (ligan Fas). Pada KPD, adanya limfosit yang menginfiltrasi tumor dihubungkan dengan angka kehidupan yang lebih baik, dan respons yang lebih baik terhadap pemberian kemoterapi berbasis antrasiklin. ${ }^{8}$

Trombosit berperan penting dalam pertumbuhan tumor. Trombosit dapat memromosikan perkembangan tumor dengan meningkatkan angiogenesis melalui sitokin VEGF. Terdapat korelasi langsung antara jumlah trombosit yang bersirkulasi dengan tingkat VEGF serum. Sel-sel tumor cenderung beragregasi membentuk gumpalan dalam sirkulasi dengan adhesi 
homotipik antar sel-sel tumor itu sendiri dan adhesi heterotipik antara sel tumor dan trombosit. Agregasi trombosit dengan sel tumor memromosikan sel tumor menjadi hidup lebih lama.

Protein reaktif C (CRP) merupakan petanda yang menggambarkan kondisi peradangan sertaa melakukan fungsi penting anti-infeksi pada sistem imun. Umumnya infeksi bakterial sistemik berhubungan dengan kadar CRP yang tinggi. Pengukuran CRP serial menunjukkan korelasi antara konsentrasi serum CRP dengan derajat keparahan penyakit dan responsnya terhadap terapi. Penigkatan CRP serum mengindikasikan adanya infeksi yang tidak terkontrol atau proses patologik yang tidak teratasi. Berbagai tipe karsinoma, terutama pada saat perkembangan ekstensif dan bermetastasis, merangsang respons fase akut. Umumnya penderita karsinoma mempunyai sistem imun yang tertekan sehingga mereka cenderung terkena infeksi sekunder yang mengakibatkan peningkatan protein fase akut, khususnya CRP. ${ }^{10}$

Pemeriksaan albumin serum merupakan metode sederhana untuk memperkirakan fungsi protein dalam tubuh. Albumin serum secara umum digunakan untuk menilai status nutrisi, derajat keparahan penyakit, perkembangan penyakit, dan prognosis. Malnutrisi dan peradangan menekan sintesis albumin. Kedua pemeriksaan protein reaktif $\mathrm{C}$ dan albumin telah diteliti dan digabungkan sebagai suatu penilaian objektif penderita karsinoma yakni skor prognostik Glasgow (Glasgow Prognostic Score $).{ }^{11}$

Dalam lima tahun terakhir, beberapa hasil prognosis penderita karsinoma khususnya KPD telah dilaporkan dengan menggunakan rasio neutrofil limfosit (NLR), rasio trombosit (TLR), protein reaktif $\mathrm{C}$, dan albumin sebagai prediktor yang terpisah. Sampai saat ini belum pernah dilaporkan gambaran penderita KPD di Indonesia dengan menggunakan keempat prediktor sebagai sistem skoring inflamasi sistemik untuk menganalisis perubahan yang terjadi sebelum dan setelah terapi pada pasien karsinoma payudara.

\section{METODE PENELITIAN}

Penelitian ini menggunakan metode intervensional analitik dengan desain potong lintang untuk menilai adanya perubahan skor respons peradangan sistemik pada penderita KPD sebelum dan setelah terapi. Penelitian dilakukan selama 1 tahun sejak bulan Mei 2014 sampai dengan April 2015. Sampel penelitian ialah wanita dengan KPD yang dirawat di RSUP Prof. Dr. R. D. Kandou Manado.

Kriteria inklusi ialah pasien wanita berusia 20-70 tahun dengan diagnosis KPD dan menyetujui untuk diikutsertakan dalam penelitian. Kriteria eksklusi ialah pasien dengan keganasan/kelainan hematologik sebelumnya, sedang dalam pengobatan steroid, dan tidak memiliki data hitung jenis darah, CRP, dan albumin.

Analisis data yang digunakan ialah analisis deskriptif serta analisis perbandingan data sebelum dan sesudah terapi dengan uji t berpasangan.

\section{HASIL PENELITIAN}

Selama periode Mei 2014 sampai April 2015 didapatkan sampel penelitian sebanyak 43 pasien KPD dengan rerata usia 52,16 $\pm 10,002$ tahun. Dari keseluruhan sampel, yang terbanyak ialah KPD stadium IIIB yaitu 25 pasien $(58,1 \%)$, diikuti oleh KPD IIIC (25,6\%), KPD stadium IIIA (11,6\%), dan KPD stadium IV (4,7\%). Modalitas kemoterapi dan operasi yang paling sering diberikan yaitu pada 40 pasien (93,0\%). Gambaran histopatologik yang paling sering ditemukan ialah jenis duktal invasif karsinoma yaitu sebanyak 34 pasien $(79,1 \%)$ sedangkan jenis lain umumnya hanya pada 1 pasien (2,3\%). Dari hasil pemantauan selama periode 1 tahun diperoleh 40 pasien yang hidup dan 3 pasien yang meninggal dunia akibat metastasis atau komplikasi (Tabel 1).

Hasil penelitian memperlihatkan bahwa setelah tindakan/perlakuan ditemukan penurunan rerata hitung neutrofil $/ \mu \mathrm{L}$ sebesar 31,9\% $(P<0,0001)$ (Tabel 2); 
peningkatan rerata hitung limfosit/ $\mu \mathrm{L}$ peningkatan rerata kadar albumin (g/dL) sebesar 31,7\% $(P<0,0001)$ (Tabel 3); $\quad$ sebesar 10,7\% $(P<0,0001)$ (Tabel 6); penurunan rerata hitung trombosit $/ \mu \mathrm{L}$ penurunan rerata nilai NLR sebesar $45,8 \%$ sebesar 15,6\% $(P<0,001)$ (Tabel 4); $(P<0,0001)$ (Tabel 7); dan penurunan penurunan rerata kadar CRP $(\mathrm{mg} / \mathrm{L})$ rerata nilai TLR sebesar $40,1 \%(P<$ sebesar 60,8\% $(P<0,004)$ (Tabel 5); 0,0001) (Tabel 8).

Tabel 1. Karakterstik pasien KPD

\begin{tabular}{lc}
\hline \multicolumn{1}{c}{ Karakteristik } & Jumlah (\%) \\
\hline Usia (tahun), rerata \pm (SB) & $52,16 \pm(10,002)$ \\
Usia (tahun) & $2(4,7)$ \\
$30-39$ & $\mathbf{1 7}(\mathbf{3 9 , 5})$ \\
$\mathbf{4 0 - 4 9}$ & $13(30,2)$ \\
$50-59$ & $8(18,6)$ \\
$60-69$ & $3(7,0)$ \\
$70-79$ & \\
Stadium & $5(11,6)$ \\
IIIA & $\mathbf{2 5}(\mathbf{5 8 , 1})$ \\
IIIB & $11(25,6)$ \\
IIIC & $2(4,7)$ \\
IV & \\
Histopatologi & $1(2,3)$ \\
Adeno Ca & $1(2,3)$ \\
Adenocystic Ca & $1(2,3)$ \\
Tubular Ca & $1(2,3)$ \\
Carcinoid Ca & $1(2,3)$ \\
Ductal cell atypic Ca & $\mathbf{3 4}(\mathbf{7 9 , 1})$ \\
Ductal invasive Ca & $2(4,7)$ \\
Invasive Papilary Ca & $1(2,3)$ \\
Lobular Ca & $1(2,3)$ \\
Cystosarcoma phylloides & \\
Modalitas & \\
Kemoterapi + operasi & $\mathbf{4 0}(\mathbf{9 3 , 0})$ \\
Kemoterapi & $2(4,7)$ \\
Operasi & $1(2,3)$ \\
Kematian & \\
Tidak & $\mathbf{4 0}(\mathbf{9 3 , 0 2})$ \\
Ya & $3(6,9)$ \\
\hline
\end{tabular}

Tabel 2. Perbedaan hitung neutrofil sebelum dan setelah terapi pada pasien KPD

\begin{tabular}{cccc}
\hline Perlakuan/tindakan & Rerata & Simpangan baku & Uji t \\
\hline Sebelum & $6.681,9767$ & $2.618,06268$ & $7,617(P<0,0001)$ \\
Setelah & $4.548,2791$ & $1.581,24585$ & \\
\hline
\end{tabular}

Tabel 3. Perbedaan hitung limfosit sebelum dan setelah terapi pada pasien KPD

\begin{tabular}{cccc}
\hline Perlakuan/tindakan & Rerata & Simpangan baku & Uji t \\
\hline Sebelum & $2.157,8140$ & 882,80511 & $-5,945(P<0,0001)$ \\
Setelah & $2.842,5814$ & $1.141,65501$ & \\
\hline
\end{tabular}

Tabel 4. Perbedaan hitung trombosit sebelum dan setelah terapi pada pasien KPD

\begin{tabular}{cccc}
\hline Perlakuan/tindakan & Rerata & Simpangan baku & Uji t \\
\hline Sebelum & $401.534,8837$ & $104.617,06790$ & \multirow{2}{*}{$3,605(P<0,001)$} \\
Setelah & $338.604,6512$ & $144.954,85989$ & \\
\hline
\end{tabular}


Tabel 5. Perbedaan kadar CRP (mg/L) sebelum dan setelah terapi pada pasien KPD

\begin{tabular}{cccc}
\hline Perlakuan/tindakan & Rerata & Simpangan baku & Uji t \\
\hline Sebelum & 16,2093 & 22,80305 & $3,033(P<0,004)$ \\
Setelah & 6,3488 & 6,06663 & \\
\hline
\end{tabular}

Tabel 6. Perbedaan kadar albumin (mg/dL) sebelum dan setelah terapi pada pasien KPD

\begin{tabular}{cccc}
\hline Perlakuan/tindakan & Rerata & Simpangan baku & Uji t \\
\hline Sebelum & 3,5153 & 0,38207 & $-9,359(P<0,0001)$ \\
Setelah & 3,9372 & 0,47474 & \\
\hline
\end{tabular}

Tabel 7. Perbedaan rasio neutrofil limfosit (NLR) sebelum dan setelah terapi pada pasien KPD

\begin{tabular}{cccc}
\hline Perlakuan/tindakan & Rerata & Simpangan baku & Uji t \\
\hline Sebelum & 3,7658 & 2,19367 & $5,586(P<0,0001)$ \\
Setelah & 2,0414 & 1,01698 &
\end{tabular}

Tabel 8. Perbedaan rasio trombosit limfosit (TLR) sebelum dan setelah terapi pada pasien KPD

\begin{tabular}{cccc}
\hline Perlakuan/tindakan & Rata-rata & Simpangan baku & Uji t \\
\hline Sebelum & 239,6279 & 94,10000 & $8,603(\mathrm{p}<0,0001)$ \\
Setelah & 143,5116 & 65,40874 & \\
\hline
\end{tabular}

\section{BAHASAN}

Pada penelitian ini ditemukan penurunan nilai NLR sebesar 45,791\% (Tabel 7). Pada suatu keganasan, NLR meningkat karena perkembangan dan penyebaran kanker. Menurut Azab et al. ${ }^{12}$ NLR sendiri lebih superior daripada parameter leukosit lain (seperti neutrofil, limfosit, dan total hitung leukosit) karena perhitungan absolut neutrofil dapat terganggu oleh berbagai faktor fisiologis, patologis, dan fisik. Di samping itu, NLR mewakili proses peradangan dan imunitas yang terdapat pada pasien kanker. ${ }^{12}$

Limfosit berperan penting pada kejadian imunitas keganasan yang menekan maturasi dari suatu tumor. Limfosit $\mathrm{T}$ sitotoksik (CTL) menginduksi apoptosis sel kanker melalui 2 jalur, yaitu: interaksi molekul CD95L (Fas ligan) pada CTL dengan molekul CD95 (Fas) pada sel target tumor; dan kerja perforin serta protease serin pada granula limfosit. ${ }^{13}$ Rendahnya nilai hitung limfosit berhubungan dengan kondisi buruk dari pasien yang terkena kanker stadium lanjut. Imunitas yang dimediasi sel-sel pada inang berlanjut dengan penghancuran sel-sel tumor residu dan mikrometastasisnya. Penelitian univariat maupun multivariat yang dilakukan Azabet al. ${ }^{14}$ melaporkan bahwa pasien dengan peningkatan hitung limfosit memiliki ketahanan hidup lebih lama dibandingkan pasien dengan hitung limfosit rendah.

Pada penelitian ini hitung neutrofil setelah terapi menurun dibandingkan sebelum terapi. Hal ini disebabkan oleh adanya perlakuan baik kemoterapi maupun operasi yang bertujuan menghilangkan tumor yang merupakan sumber sitokin kemotaksik yang berkeja memicu neutrofil untuk bermigrasi ke arah tumor. Dengan hilangnya tumor, tidak ada lagi sinyal untuk menarik neutrofil sehingga tubuh tidak memroduksi neutrofil secara berlebih. $^{15}$

Pemberian kemoterapi dan operasi pada penderita KPD membuat sistem imun tubuh menjadi lebih baik. KPD yang melemahkan keadaan umum serta menekan sistem imun penderita dihilangkan sehingga produksi limfosit sebagai pembentuk antibodi tubuh meningkat kembali. $^{16}$

Trombosit berperan penting pada 
perkembangan tumor dan dapat memromosikan pertumbuhan tumor dengan meningkatkan angiogenesis melalui sitokin VEGF. Terdapat korelasi langsung antara jumlah trombosit sirkulasi dengan tingkat VEGF serum. Wiesner $\mathrm{T}$ et al. mendapatkan bahwa VEGF-A secara bermakna meningkat pada pasien dengan keganasan dibandingkan kontrol. Sel-sel tumor berkumpul membentuk aggregasi dalam sirkulasi akibat adhesi homotipik antar selsel tumor itu sendiri dan adhesi heterotipik antara sel-sel tumor dan trombosit. ${ }^{17}$ Pada penelitian ini diperoleh penurunan nilai TLR sebesar 40,11065\% $(P<0,0001)$ yang menunjukkan trombosit sebagai bahan promosi pertumbuhan dan perkembangan tumor ditekan menjadi lebih rendah setelah perlakuan kemoterapi dan/atau operasi. Hal ini disebabkan karena tumor merangsang pembentukan trombosit untuk melindungi tumor dari sel NK dan TNF- $\alpha$. Selain itu trombosit memiliki protein angiogenesis yang penting sehingga penyebaran dan progresifitas tumor menjadi lebih tinggi. Dengan menghilangkan massa tumor, tidak ada lagi sumber yang merangsang pembentukan trombosit sehingga produksi trombosit kembali menjadi normal.

Terdapat dua hipotesis mengenai hubungan antara kadar CRP dan keganasan. Yang pertama, peningkatan CRP merupakan akibat dari adanya kanker itu sendiri. Yang kedua, inflamasi kronik dan CRP yang tinggi menjadi penyebab utama terjadinya karsinogenesis. Kerusakan oksidatif akibat inflamasi dapat menginisiasi karsinogenesis dengan menginaktifasi gen penekan tumor atau modifikasi pada protein perbaikan DNA pasca translasi atau kontrol apoptotik. Sebagai tambahan, sitokin inflamasi memberi sinyal melalui enzim intrasel dan faktor-faktor transkripsi yang hasil akhirnya menghambat apoptosis dan memromosikan pertumbuhan dan perkembangan sel-sel kanker. Aktivasi jalur inflamasi memfasilitasi perkembangan tumor dengan memromosikan motilitas sel, permeabilitas pembuluh darah, dan angiogenesis. $^{18}$
Secara mekanisme, terdapat tiga komponen yang menjelaskan hubungan antara peningkatan kadar CRP plasma dan prognosis keganasan payudara. Pertama, sifat sel tumor: kadar CRP plasma merefleksikan agresifitas tumor; oleh karena itu, kadar CRP plasma memberikan informasi prognostik karakteristik tumor (seperti stadium dan gradasi tumor). ${ }^{16}$ Penelitian Roxburg CS et al. ${ }^{17}$ melaporkan peningkatan kadar CRP berhubungan dengan ukuran tumor, adanya metastasis jauh, dan gradasi tumor. Kedua, inflamasi sekitar: kadar CRP plasma mengekspresikan keadaan lingkungan mikro tumor payudara. Jalur inflamasi berperan penting di tiap tingkatan tumorigenesis, meliputi inisiasi dan promosi tumor, transformasi keganasan, invasi tumor, dan metastasis. ${ }^{17}$ Tumor padat memicu respons inflamasi yang menghasilkan formasi lingkungan mikro yang pro-tumorigenik dan proangiogenik sekitar tumor. Sel-sel radang dan imunitas pada lingkungan mikro tumor berinteraksi dengan sel-sel keganasan, dan sebagai hasil akhir ialah stimulasi pertumbuhan tumor, invasi, dan metastasis. Ketiga, sifat inang: kadar CRP plasma menggambarkan keadaan umum wanita saat didiagnosis menderita KPD. Pada penelitian West NR et al. $^{18}$ diperoleh peningkatan kadar CRP berhubungan dengan merokok dan indeks massa tubuh penderita yang besar.

Christopher et al mengatakan kadar serum albumin yang rendah berhubungan dengan perubahan metabolik yang diakibatkan oleh stres, penyakit, insufisiensi hati, dan pengurangan massa protein organ dalam atau penurunan kemampuan sintesis albumin sehingga harus dipertimbangkan dalam penentuan kecukupan keadaan nutrisi serta kebutuhan penunjang nutrisi. Penunjang nutrisi yang agresif pada penderita keganasan sangat efektif untuk memelihara status nutrisi saat menerima seluruh terapi sehingga memberikan efek yang positif. ${ }^{19}$ Selain itu, saat dihilangkan sumber tumor yang melemahkan penderita membuat menjadi malnutrisi, penurunan nafsu makan, serta mengganggu sintesis 
protein di hati, keadaan penderita menjadi baik sehingga terjadi peningkatan produksi albumin dalam tubuh. ${ }^{20}$

Pada penelitian ini kadar albumin meningkat sebesar 10,715\% $(P<0,0001)$ pada pasien KPD sebelum terapi dan setelah terapi. Dari keseluruhan parameter yang diuji pada penelitian ini, tergambar bahwa penurunan paling tinggi terjadi pada nilai CRP kemudian diikuti berurutan nilai NLR, TLR, dan kadar albumin. Hal ini berhubungan dengan CRP sebagai petanda inflamasi yang akan menurun bila keadaan penyebab primer inflamasi telah diatasi/ diberi perlakuan. Perubahan nilai NLR dan TLR tidak jauh berbeda; keduanya merupakan komponen dari darah, sedangkan yang paling kecil pengaruh pemberian kemoterapi dan/atau operasi ialah nilai albumin.

\section{SIMPULAN}

Tindakan yang diberikan baik kemoterapi dan/atau operasi pada penderita KPD memengaruhi kondisi hemopoetik yaitu terjadi penurunan nilai hitung neutrofil, hitung trombosit, NLR, TLR, dan kadar CRP, serta peningkatan nilai hitung limfosit dan kadar albumin saat dibandingkan sebelum dan setelah diberikan perlakuan.

\section{SARAN}

1. Perlu penelitian lanjut yang melibatkan subjek dan senter penelitian yang lebih banyak, waktu pemantauan lebih panjang, serta mengikuti perkembangan penderita KPD hingga siklus kemoterapi lengkap, agar diperoleh komponen yang lebih sensitif dalam memrediksi prognosis ketahanan hidup.

2. Perlu penelitian lebih lanjut apakah rasio neutrofil limfosit, rasio trombosit limfosit, protein reaktif $\mathrm{C}$, dan albumin lebih superior dibandingkan petanda protein fase akut lainnya seperti fibrinogen, serum amyloid A, haptoglobulin, YKL-40, dan sitokin proinflamasi.

\section{DAFTAR PUSTAKA}

1. Siegel R, Naishadham D, Jemal A. Cancer statistics 2012. CA Cancer J Clin. 2012;62:10-29.

2. Tjindarbumi D, Mangunkusumo R. Cancer in Indonesia: present and future. Jpn J Clin Oncol. 2002;32 (Suppl.1):S17-S21.

3. Mantovani A, Marchesi F, Porta C, Sica A, Allavena P. Inflammation and cancer: breast cancer as a prototype. Breast. 2007;16:S27-S33.

4. Rodenhiser DI, Andrews JD, Vandenberg TA, Chambers AF. Gene signatures of breast cancer progression and metastasis. Breast Cancer Res. 2011;13:201-8.

5. Al Murri AM, Hilmy M, Bell J, Wilson C, McNicol AM, Lannigan A, et al. The relationship between the systemic inflammatory response, tumor proliferative activity, T-lymphocytic and macrophage infiltration, microvessel density and survival in patients with primary operable breast cancer. $\mathrm{Br} \mathrm{J}$ Cancer. 2008;99:1013-9.

6. Tavares-Murta BM, Candido-Murta EF. Systemic leukocyte alterations in cancer and their relation to prognosis. Open Cancer J. 2008;2:53-8.

7. Bambace NM, Holmes CE. The platelet contribution to cancer progression. J Thromb Haemost. 2011;9:237-49.

8. Peisajovich A, Marnell L, Mold C, Du Clos TW. C-reactive protein in the interface between innate immunity and inflammation. Expert Rev Clin Immunol. 2008;4(3):379-90.

9. Heikkila K, Ebrahim S, Lowlor DA. A systematic review of the association between circulating concentration of $\mathrm{C}$ reactive protein and cancer. $\mathrm{J}$ Epidemiol Community Health. 2007;61:824-33.

10. Gupta D, Lis CG. Pretreatment serum albumin as a predictor of cancer survival: A systematic review of the epidemiological literature. Nutr J. 2010;9:69-81.

11. Townsend CM, Beauchamp RD, Evers BM, Mattox KL. Sabiston Textbook of Surgery (19th ed.). Philadelphia: Elsevier Saunders, 2012; p. 824-67.

12. Azab B, Bhatt V, Phookhan J, Murukutla S, Kohn N, Terjanian $T$, et al. Usefulness of the neutrophil-tolymphocyte ratio in predicting short and long term mortality in breast cancer 
patients. Ann Surg Oncol. 2012;19:21724.

13. Noh H, Eomm M, Han A. Usefulness of pretreatment neutrophil to lymphocyte ratio in predicting disease specific survival in breast cancer patients. J Breast Cancer. 2013;16:55-9.

14. Azab B, Shah N, Radbel J, Tan P, Bhatt V, Vonfrolio D, et al. Pretreatment neutrophil/lymphocyte ratio is superior to platelet/lymphocyte ratio as a predictor of long term mortality in breast cancer patients. Med Oncol. 2013;30:432-41.

15. Kwon HC, Kim SH, Oh SY, Lee S, Lee JH, Choi HJ, et al. Clinical significance of preoperative neutrophil-lymphocyte versus platelet-lymphocyte ratio in patients with operable colorectal cancer. Biomarkers. 2012;17(3):216-22.

16. Al Murri AM, Bartlett JM, Canney PA, Doughty JC, Wilson C, McMillan DC. Evaluation of an inflammation-based prognostic score (GPS) in patients with metastatic breast cancer. $\mathrm{Br} J$ Cancer.2006;94:227-30.

17. Roxburg CS, McMillan DC. Role of systemic inflammatory response in predicting survival patients with primary operable cancer. Future Oncol. 2010;6:149-63.

18. West NR, Milne K, Truong PT, Macpherson N, Nelson BH, Watson PH. Tumor infiltrating lymphocytes predict response to anthracycline-based chemotherapy in estrogen receptornegative breast cancer. Breast Cancer Res. 2011;13(6):R126.

19. Gnvennikov SI, Greten FR, Karin M. Immunity, inflammation, and cancer. Cell. 2010;140:883-99.

20. Christopher S, Glare P, Downing M, Stone $\mathbf{P}$, Maltoni $\mathbf{M}$, Vigano $A$. Predicting survival in patients with advanced disease. Eur J Cancer. 2008;44:1146-56. 